Article

\title{
Social Evaluation Approaches in Landscape Projects
}

\section{Saverio Miccoli ${ }^{1, *}$, Fabrizio Finucci ${ }^{2, \dagger}$ and Rocco Murro ${ }^{1, \dagger}$}

1 University of Rome La Sapienza, DIAP, P.zza Borghese 9, 00186 Rome, Italy;

\section{E-Mail: rocmurr@tin.it}

2 University of Roma Tre, Department of Architecture, Via della Madonna dei Monti 40, 00184 Rome, Italy; E-Mail: fabrizio.finucci@uniroma3.it

$\dagger$ These authors contributed equally to this work.

* Author to whom correspondence should be addressed; E-Mail: saverio.miccoli@uniroma1.it; Tel.: +39-06-4991-8895; Fax: +39-06-4991-8894.

External Editor: Marc A. Rosen

Received: 1 August 2014; in revised form: 31 October 2014 / Accepted: 4 November 2014 /

Published: 10 November 2014

\begin{abstract}
Landscape is a crucial component of world heritage and, in the last few years, landscape projects have played a vital role in the development of sustainable scenarios. As reported in the European Landscape Convention, landscape means an area, as perceived by people, of which the character is the result of the action and interaction of natural and/or human factors. Therefore, in landscape planning and assessment, the community is necessarily involved. In order to improve the effectiveness of a project for landscape enhancement, this study suggests strategies for an integrated project, taking into account the numerous, heterogeneous variables involved. A landscape project, therefore, is a complex project that requires structured valuation stages, open to the community dimension. The qualitative, intergenerational, and inclusive characteristics of landscapes suggest that the limits of traditional economic analysis should be exceeded by adopting new assessment methods. With this aim in mind, this paper proposes social evaluation approaches, which operate by combining deliberative processes with total economic and multidimensional approaches. In this paper, we present: (1) a brief overview of the main features and issues concerning landscape projects; (2) strategies for integrated projects in landscape enhancement; and (3) social approaches in landscape assessment that account for complexity and social inclusion.
\end{abstract}


Keywords: landscape assessment; monetary valuation; multidimensional valuation; social inclusion; sustainable projects

\section{Introduction}

As a result of society's growing interest in aesthetic and cultural aspects of territory, landscape projects have become more important and more widely known over the last few years. A landscape project mirrors the urgent need for an instrument to implement public policies aimed at strengthening the social use of landscape and fighting against the uncontrolled consumption of the land.

A favorable climate to actions aimed at protecting, enhancing, and suggesting new uses of landscape, has emerged thanks to three simultaneous factors [1]: (a) civil society has acknowledged that landscape is a primary factor of the community's welfare; (b) public administrators and political classes have become aware that protecting beauty, nature, and culture pays off in terms of social approval; and (c) the business community has realized that the return on investments on the quality of landscape and the environment is remarkable.

In this paper, the label "landscape project" entails an extended reference to all operational instruments (programs, plans, projects, etc.) used to conceive actions on a territory, including the whole project development process (pre-feasibility and feasibility studies, preliminary, final, and detailed design).

Whereas a certain expertise was available on drafting architecture, city planning, and restoration projects, when landscape-planning requests started to increase, there was not yet a consolidated professional skillset. On the other hand, the history of civilization had never seen such drastic degradation of the landscape, nor had the large-scale need, from aesthetic and cultural viewpoints, ever emerged for protecting and enhancing, as well as creating and restoring, landscapes or actively managing valuable environments.

While the theory and practice of the landscape sector have been well established for quite some time, both aspects still need to evolve. This is also true for many professional sectors and disciplines interacting in landscape project development; in particular, this holds true for assessment activities that have been preceded by a similar situation in regards to initiatives dealing with historical and cultural heritage. Especially from the theoretical viewpoint, analogizing heritage and landscape issues can be fruitful.

The value of landscape is based on interpretations of reality aimed at meeting qualitative needs. It has emerged in societies that have already met primary needs and are characterized by high income, education and leisure levels, with in turn influence lifestyles of individuals and community.

In today's world, the role that qualitative values have taken on called for revising the theory of development, in which human beings are now considered the ultimate end, as well as the utility function, now based on the pursuance of a number of qualitative objectives. In practice, the traditional economic dimension has been complemented with social and environmental-cultural dimensions. This integrated approach is opposed to growth models exclusively based on economic-quantitative approaches.

The European Landscape Convention [2] enshrines a series of concepts from which other crucial indications may be derived to develop an overall framework of reference to assess a landscape project. 
The convention acknowledges landscape as a fundamental component of European heritage. Its distinctive features imply that the landscape setting of a location includes tangible and intangible, physical and cultural, natural and manmade resources; their joint and intertwined action does not necessarily lead to organic balance conditions but implies the search thereof. Landscape should be given a constant and crucial role in any plan, project, or program aimed at developing a territory.

The acknowledgment of the landscape value of an area is based on what is perceived as such by a given population, according to their culture in a given period. Perception leads to judgments, which, in the same area, may involve different responses, either positive or negative, on the landscape settings considered. After all, the identification of a landscape, based on a community's perception and interpretation, entails a dynamic vision leading to the conception of different landscape scenarios liable to be modified in time.

Landscape stimulates the local cultures, consolidates and represents the identity of a population, and contributes to the welfare of human beings [3]; all these repercussions can lead to important advantages from the viewpoint of the promotion of human beings, from both the social and individual perspectives.

Difficulties will clearly emerge in the procedures aimed at defining the public interest of a given landscape resource, as well as the relation between the natural and manmade heritage or between traditional and contemporary aspects.

Any intervention on landscape entails basic precepts, i.e.,

- the landscape does not only have intrinsic value - i.e., an environmental and cultural good_-but also has a social value, in light of its contribution to the welfare of the community;

- intervention procedures on the landscape should be compatible and consistent with the actions aimed at development and protection, since any action on the territory produces effects on the landscape and any action entails repercussions on territory transformation processes;

- landscape problems should be solved with a view to an active, dynamic and creative management of the good, thus avoiding mere limitations and passive defense provisions;

- a landscape project should provide the starting point to develop a modern vision of the territory and be the result of a careful analysis of the existing potential and incompatibilities;

- landscape issues should be dealt with according to an integrated approach, along with urban, regional, environmental, and infrastructural issues, jointly framed within a sustainable development scenario;

- landscape policies call for participatory planning involving civil society, public institutions, and operators, and accounting for both local and global needs.

The principles illustrated above, and their interrelations, call for explicitly checking the decision-making process during the project development stage.

\section{Strategies for Landscape Integrated Enhancement}

Landscape may play a strategic role if it is considered the starting point of urban, territorial and environmental regeneration processes. In this respect, the first sites to be involved should include spaces of culture, beauty, emotion and socializing of a given community [4]. Thanks to those values, such spaces encourage participation, communication and information, i.e., crucial factors in guiding the development process towards shared goals and successful results. 
Through enhancement interventions, their visibility with the public would be strengthened and there would be greater opportunities for further uses and safeguarding activities. More specifically, integrated enhancement actions could emerge, based on the diverse characteristics of the good and a heterogeneous flow of interconnections between the good itself and the context in which it is set [5]. If the set of needs of the territory is taken into account creatively and rationally, integrated landscape enhancement contributes to the regeneration of the physical contexts involved and the relations among subjects operating in such contexts.

In territories characterized by widespread presence of landscape, environmental, historical and cultural resources, territory regeneration processes should constantly base their strength on a set of such social attractors and exploit their enhancement to trigger widespread regeneration effects over the whole territory taken into account in order to obtain a driving effect on related activities.

The outcome of a landscape project depends on the ability to strike a balance among a number of heterogeneous and often conflicting variables.

For this purpose, the project has to assume a central role with reference to the contributions of distinct disciplines necessary for its drafting. This means that, from a theoretical viewpoint, the collaboration is necessary of a number of disciplines, as well as, from the operational viewpoint, the participation of a number of professional skills. Substantially, a landscape project is to be considered the aesthetic and formal representation of an idea, albeit as a unitary synthesis integrated by distinct specialized proposals.

The project has to be seen as the technical implementation of the community's claims (needs, preferences, objectives, etc.) by the integrated planning team. Social consensus may be considered a vital prerequisite to implement the project; from this perspective, landscape planning procedures call for developments based on the participation of subjects involved in their implementation and the use of dialog to negotiate among different stances.

In addition, the identification of a set of protection, management, and planning interventions is necessary, thereby, envisaging a number of different actions: from preservation to restoration, from recovery to regeneration, from enhancement to land transformation and urban development. Moreover, a broad survey of the territory involved is useful to understand the past, present and future evolution of its physical, social, economic and cultural settings. Such a complex operation necessarily entails the evaluation of aspects such as consistency, effectiveness and equity.

The implementation of the complex set of interventions described above finds its strength in the collaboration of different operators, in the negotiation among subjects involved, in the use of public and private financial resources and different financing instruments. The complexity factors mentioned above provide an overview of the kind of problems that landscape planning needs to face, of which a realistic solution inevitably calls for an integrated approach (Table 1).

In summary, a landscape project should always be an integrated project, capable of interpreting the complexity of reality, i.e., accounting for numerous, heterogeneous, sometimes clashing, variables [6]. The project should provide a unitary and creative response to that set of variables, not all of which may be streamlined, although one overall solution may be preferable. An integrated approach to a landscape is rarely described in the literature, and sector-oriented approaches also predominate the main groups of landscape functions, that is, economic (production-oriented), ecological (regulatory), and social (cultural, aesthetical, ethical, psychological, and recreational) [7]. 
Table 1. Key elements for integrated landscape project.

\begin{tabular}{ll}
\hline \multicolumn{1}{c}{ Issue } & \multicolumn{1}{c}{ Integrated Approach } \\
\hline Sector-oriented, partial, reductionist approach & Contributions of distinct disciplines, holistic approach \\
\hline $\begin{array}{l}\text { Hierarchical, top-down approach; assessment } \\
\text { by expert }\end{array}$ & $\begin{array}{l}\text { Bottom-up: technical implementation of the } \\
\text { community's claims by the integrated planning team }\end{array}$ \\
\hline $\begin{array}{l}\text { Individual, mono-functional partial actions on } \\
\text { separate system }\end{array}$ & $\begin{array}{l}\text { Identification of a set of protection, management and } \\
\text { planning interventions envisaging a number of } \\
\text { different actions }\end{array}$ \\
\hline Centralized decision nodes & $\begin{array}{l}\text { Collaboration of different operators, negotiation } \\
\text { among subjects involved }\end{array}$ \\
\hline $\begin{array}{l}\text { Entirely private or entirely public financial } \\
\text { resources and traditional financial instruments }\end{array}$ & $\begin{array}{l}\text { Use of public and private financial resources and } \\
\text { different financing instruments }\end{array}$ \\
\hline
\end{tabular}

\section{Complexity and Social Inclusion: Evaluation Procedures}

Until recently, project evaluation meant assessing the costs and profitability of an intervention; today, it is a tool to estimate different values and to select or conceive planning alternatives. In particular, landscape project peculiarities call for radically renewed assessment principles, techniques and approaches.

Landscape assessment should not be seen as a set of autonomous, occasional and unstructured stages, but as a logical and structured process applicable to all project stages, decisions, and alternative hypotheses [8]. It should be extended to different project scales, from the most general and preparatory to the most analytical stages (preliminary, final, and detailed design). All the decisions made, based on the assessment process, should be mutually consistent and consequential.

Especially at the most general planning stages, the need emerges to introduce adequate assessment procedures, i.e., when indeterminate elements come into play and call for instruments aimed at their progressive limitation and combination to obtain effective, efficient and consistent results. The greater the use of broader scale assessment, the greater the quality of the final and detailed design. From the strategic viewpoint, fundamental planning choices are made on those scales, whereas the verification and thorough analysis of decisions already made take place on more detailed scales.

In general, the scenario which may serve as context to assess a landscape project is defined by the elements included in the sustainable development equation, based on the relation between the economic, social and environmental dimensions [9]. The hierarchy of variables that come into play is to be configured according to different transient situations; however, by means of the assessment process, dominant project alternatives should be developed, i.e., they should tend to pursue all objectives effectively and simultaneously.

Landscape is properly a public good and, as such, fulfils a subsidiary function by meeting needs and preferences based on qualitative values [10,11]. The qualitative, intergenerational and inclusive characteristics of landscape suggest that, in assessment procedures, the limits of traditional economic analysis [12] (which tends to consider only short-term monetary effects and only those affecting direct users) should be exceeded by adopting new methods proposed by environmental economics. These methods base their analyses and assessments on the study of external economies (utilities and disutilities dispensed without compensations), intangibles (utilities and disutilities not directly quantifiable and including extra-economic aspects), and long-term effects (utilities and disutilities calculated over 
extensive periods of times, suitable for considering the net benefits of future users). In brief, making decisions in terms of actions affecting the landscape without considering externalities, intangibles and long periods, i.e., according to a partial outlook on the costs and benefits of the action, would lead to advantages for few and damage for many, in addition to damaging the good.

Consequently, a crucial perspective that may be adopted to assess landscape projects is a social viewpoint. To this end, an assessment has to be developed depending on the impacts produced by the project on the community, i.e., according to the interpretation of those who are actually affected in order to produce a social evaluation. The interpretation has to be related to an integrated approach extending the contextual and contemporary reading of landscape project features to different dimensions: technical, functional, environmental, social, economic, procedural, and historical-cultural. Effects are not assessed per se; rather, they are assessed in the light of their repercussions on community and according to their positive or negative perception relative to all the considered dimensions. Stakeholder knowledge is essential, since disciplinary expert evaluations and existing proxy data on landscape services reveal very little of the landscape benefits to the local stakeholders [13]. This local knowledge emerges from personal observation and environmental experience, and is related to the subjective perceptions and valuation of the landscape [14-16].

According to its qualitative features, a landscape has an impact not only on its direct users but also on the community welfare; therefore, the value and assessment of a landscape project should express the appreciation of a community for that project.

\subsection{Evaluation Criteria}

In assessing a landscape project, reference can be made to different criteria and procedures. Within the Italian scientific circles, over thirty years ago Carlo Forte identified the "social use value" [17] as a criterion to assess cultural real estate. It did not coincide with the market value since it was a broader concept, including social, environmental, cultural values that could be expressed in monetary terms.

According to Marshall's interpretation and based on the aggregate demand curve, the social use value of a good amounts to its exchange value plus the consumer's surplus amounting to the monetary sum that consumers are willing to pay in addition to the exchange value for the total utility received from that good.

A landscape project may be assessed according to the economic dimension and to a single monetary criterion by assessing its total economic value.

In regards to marketed benefits, their base value may be inferred according to traditional estimation criteria (market value, cost value, etc.). In contrast, their total economic value [18] may be derived from their use value plus a non-use value (or passive use value) depending on the characteristics of the resource for which the community is willing to pay. If non-marketed benefits emerge, the total economic value is to be calculated as above, through estimate processes suitable for expressing benefits in monetary terms.

In expressing the passive use value [19], the literature available resorts to the concept of the existence value, excluding all values deriving from current and future, direct or indirect, real and potential uses from its analysis [20]. It expresses the value of a landscape connected to its peculiarity, regardless of the instrumental role it may play for human beings. The estimate of the existence value is subject to the 
possibility of ascertaining the willingness to pay for the mere knowledge that a given resource exists, regardless of its actual use.

There is abundant literature on techniques for valuing landscapes, and there are studies that review this corresponding literature [21,22]. To express benefits in monetary terms, two sets of techniques are generally used: Revealed Preference Techniques and Stated Preference Techniques. The former are based on complementary (or surrogate) markets, by evaluating benefits through the effects that a non-marketed good produces on the actual market of other goods. The latter set refers to hypothetical markets, based on surveys carried out on representative samples of the community. Interviewees are asked to express the economic value attributed to non-marketed benefits. Both techniques may be used to evaluate the use value, but only Stated Preference Techniques (classified as Contingent Valuation and Choice Modeling Techniques) lead to estimate the passive use value, which may be assessed according to the willingness to pay of interviewees [23]. In landscape evaluation, it is possible to find contingent valuation studies, such as Sayadi et al. [24], Morey et al. [25] or González et al. [26], and Moran et al. [27].

For a more rigorous assessment, Choice Modeling Techniques seem to be preferable because they can account for the attributes playing a crucial role in the calculation of the total economic value; it allows estimating monetary values of landscape changes, which is comparable to implementation costs, provides more detailed information and makes it possible to measure the benefits associated with the implementation of multidimensional policies with an impact on non-use (passive-use) economic values [28-30]. These advantages are counterbalanced by the greater costs and longer time required by these techniques to complete the assessment procedure [31]. Choice Modeling applications to landscape are expanding rapidly [32-39].

The total economic value may be considered the assessment criterion most similar to estimate logic and allows the obtaining of an objective measurement of the impact of public action on landscapes, which is comparable to implementation costs [40].

As an alternative to monetary valuation, a landscape project may be assessed by using a multidimensional approach that conveys the global value of the project deriving from the fundamental dimensions of sustainable development (economic, social and environmental component) [41] while accounting for equity aspects, i.e., the correct distribution of effects among different social groups. By means of this approach, the assessment of a landscape project may be based on the analysis of attributes connected to its different impacts and may express the final outcome in non-monetary terms.

The selection among various project alternatives is made according to an overall multidimensional procedure aimed at the simultaneous assessment of the project: (a) with reference to different (economic and non-economic) dimensions; (b) accounting for the interdependent synergies and conflicts at hand; (c) studying the various viewpoints of the subjects involved; and (d) resorting to quantitative and qualitative (monetary and non-monetary) evaluation scales.

Substantially, a multidimensional approach gives the possibility of making decisions in complex conditions and choosing and developing project profiles that are well balanced and more preferable, and are the outcome of acceptable compromises [42].

Assessment techniques based on multidimensional approaches are multi-criteria and multi- objective analyses [43]. By weighing their various assessment criteria, they lead to choices based on precise alternative scenarios. Different levels of preference may be associated with economic or environmental, 
aesthetic or functional, social or individual, public or private aspects, leading to assessments that reflect the multiple elements coming into play [44].

There is a growing consensus about the suitability of the multidimensional approach when dealing with natural resource management problems and environmental planning, areas in which there are many conflicting interests [45]. The opportunities offered by multi-criteria and multi- objective analyses for choosing among "discrete" and "continuous" mathematical models and quantitative, qualitative and mixed scales support the planner's choices when limited or unlimited alternatives exist and encourage the search for the most preferable solution. Mention must be made of the difficulties emerging from the language used to analyze some categories of intangible values (e.g., aesthetic, perceptive, historical, cultural, psychological categories, etc.), as well as the great potential for controlling a complex system of variables and reaching a synthesis by formulating a final overall judgment [46].

Malczewski [47] documented the increase in use of multidimensinal approaches in synergy with the capabilities of the geographical information systems (GIS) in the last two decades. This occurred in a broad range of applications, such as land use planning [48], transportation infrastructure [49,50], urban planning [51], environmental planning [52,53], and forest restoration [54-56].

\subsection{Social Approaches}

The number of interests likely to be aroused by a landscape project calls for an assessment process open to the general public [57]. This essentially means that any assessment should: (a) operate from a social viewpoint, by highlighting the distribution of the impact of the project on the subjects involved; and (b) involve the community in planning choices, by defining criteria and priorities upon which the values estimation and selection of alternatives should be based [58].

The assessment of social effects of the various planning alternatives leads to the expression of the distribution equity level [59] of each one of them and, consequently, to the selection of the most satisfactory; otherwise, to the improvement - through dialog, negotiation, and communication with the project stakeholders - of the social profile thanks to the alternative having the greatest potential. In short, an assessment process should ascertain not only "if" and "how much" a given planning alternative is valid, but also "for whom". This is obtained through the assessment of the project impact according to a disaggregate analysis based on its users.

Each phase arouses a variety of interests, different and often conflicting, to be taken into account if the objective is to outline the most balanced project profile, considering the growing active role that civil society has in urban, regional and environmental choices. Therefore, the configuration of project scenarios is likely to arise increasingly from collective visions and concerted actions, for which it is crucial that the community participates [60].

The main mature democracies are going through a progressive crisis of the representative model that leaves out the community from the decision-making process. Consequently, the experiences of direct democracy spread rapidly, with the purpose of overcoming the current sporadic and experimental condition on a stable and ordinary one [61]. Although such democratic forms can only complement representative democracy, the substantial benefits that these forms can bring in terms of promoting social capital [62] and detecting collective preferences, especially when the latter cannot be revealed in actual markets, must be pointed out. 
In recent years, on the issue of public participation in the choices for the territory, the evaluation methodology has developed considerably in the wake of environmental issues and community measures. The new participatory procedures are based on sharing, cooperation, exchange of knowledge and creative contributions between project promoters and citizens, operators, in addition to interest groups aiming at contributing in different ways to the solution of problems. These procedures, by means of the direct involvement of citizens in decision making, can provide the theoretical and operational basis for an advanced valuation, in tune with the common feeling of citizens, who on the one hand are aware of the increasingly critical situations produced by traditional forms of representative democracy and, on the other, are prone to a wide introduction of direct democracy instruments, which in many respects appear to be more appropriate to socially reflect on the relationship between means and shared objectives. The potential and accuracy of involving local people in landscape management and planning is explicitly expressed in both the Convention on Biodiversity (1991), the European Landscape Convention and the Aarhus Convention of UNECE (United Nationals Economic Commission for Europe) 1998 [63].

Participatory approaches have been applied to landscape management and planning in many studies, such as Hilts [64], Baker [65], Berkes [66], Buch and Hoverman [67], and O'Riordan and Stoll-Kleemann [68]. Participatory methods are numerous and may be classified according to the share of power transferred from the institutional decision maker to the participatory context [69].

From the most recent practice emerged the need for adopting non-linear, dynamic approaches to participation in landscape management rather than linear top-down or bottom-up approaches. Such inclusive approaches require a focus on relationships involving dialog between people [70]. For this reason, directly deliberative procedures based on assemblies, groups or citizens' juries become more consolidated. Among the various deliberative techniques developed over the years, we mention the Plannungszelle [71], the Citizen Juries of Ned Crosby [72], the Opinion Deliberative Polls [73], and the Consensus Conferences [74]. Applying these techniques, the outcome is a preference expressed on the basis of informed, conscious and consensual choices and obtained by highlighting one's own opinions, discussing them and changing them after they have been debated. Information and dialog are the prerequisite and fundamental elements of a procedure which is direct, as citizens directly participate in the solution of problems, and deliberative, since the decisions affecting the community should be taken with an adequate information base and argued with much discussion and convincing reasons.

The landscape assessment procedures (both monetary and multidimensional) integrated with deliberative processes lead community actors to express judgments, both in terms of value and choice, through an informed, dialogical negotiation [75] and sociable relationship with stakeholders [76]. This leads to the progressive reduction of the areas of conflict, outlining balanced profiles between strong stakeholders and the advocates of common good that often have no voice. This means the inclusion of all stakeholder views on an equal basis, the inclusion of the emotional, as well as the rational, the personal and the professional, and the objective and the subjective aspects of landscape and their relationship with it [70].

Judgments are expressed either individually by the members of a group or in the name of the group as a whole. In conclusion, a deliberative participatory valuation procedure allows expressing a fairer and more democratic value judgment, since it is the result of consensual and shared social choices.

Finally, an assessment procedure contributing to choose or develop a more democratic and equitable planning alternative through socially shared choices is a vital prerequisite for a successful project, both 
in the drafting and implementation stages. This approach may lead to more effective planning based on sustainable development principles (Table 2).

Table 2. Differences between conventional and deliberative approaches in landscape assessment.

\begin{tabular}{ll}
\hline \multicolumn{1}{c}{ Conventional Approaches } & \multicolumn{1}{c}{ Deliberative Approaches } \\
\hline $\begin{array}{l}\text { Little information based on few sources, } \\
\text { no discussion }\end{array}$ & Informed and discussed evaluation \\
\hline Authoritative, exclusive or delegated decision & $\begin{array}{l}\text { Democratizing deliberation, } \\
\text { legitimating decision and process }\end{array}$ \\
\hline $\begin{array}{l}\text { Biases and strategic behavior } \\
\text { which generate mis-measurement }\end{array}$ & Little biases and better measurement \\
\hline Valuation as a technical and individual process & Valuation as a social process \\
\hline No evolution or improvement of community & Growing sense of community \\
\hline $\begin{array}{l}\text { Difficulties in analyzing and solving } \\
\text { complex problems }\end{array}$ & Easier analysis and solution of complex problems \\
\hline
\end{tabular}

\section{Conclusions}

At the European level, after the agreement of the European Landscape Convention, two very innovative concepts emerged: the first gives landscape a dominant function for the welfare of populations; the second underlines the opportunity to operate on landscape through integrated enhancement projects, consistently with the principles of sustainable development and a compatible use of the territory. Although it is the outcome of cultural and relational processes, the final result is very important because it provides the best possible platform to start concrete, shared and high-quality operations all over Europe.

The implementation of public landscape policies is increasingly included in the programs of the local governments. However, the successful protecting and enhancing initiatives envisaged by landscape planning will mainly depend on the ability of governments to welcome and implement the general guidelines illustrated above in their own local planning instruments. After all, with reference to landscape initiatives, an efficient public sector-protecting the public interest-as well as a more authoritative and responsible civil society and a greater and more widespread citizen awareness play crucial roles.

The main novelties in the assessment procedures offered derive from complexity factors caused by the number of features involved in any landscape context; consequently, traditional economic and evaluative methods prove unsuitable. Externalities and intangibles, quality and sustainability, social use and civil participation are only part of the many elements contributing to two approaches: (a) a total economic approach capable of accounting for a broader set of values that can somehow be expressed in monetary terms; and (b) multidimensional solutions capable of considering all the values at hand and avoiding difficult monetary conversion.

These procedures, integrated with deliberative approaches, allow the landscape project, complex and of public interest, to reach more efficient and socially shared solutions.

As mentioned above, the acknowledgement of landscape value is based on perception and interpretation of a community, which, therefore, has to be necessarily involved in decisions relating to 
the landscape project. While it may be perceived as an additional charge of the decision-making process, the deliberative evaluation of the landscape, as it was based on discussions and critical inter-subjective judgments, is characterized by objectivity and features of public ethics. On the one hand, the ability to formulate and implement rational critical judgments stimulates the activation of revisions and progressive improvements in the decisions that affect the community and, above all, facilitates an efficient implementation; on the other hand, taking into account the distribution of utility and disutility perceived by different actors, it is possible to contribute with awareness and transparency in order to improve project solutions and increase the degree of social equity.

The landscape project is an occasion to open new horizons for the evaluation practice, updating investigative and operative procedures based on the current requests of society, economy and ecological citizenship.

\section{Author Contributions}

The authors contributed equally to this work.

\section{Conflicts of Interest}

The authors declare no conflict of interest.

\section{References}

1. Miccoli, S. Evaluation Principles in Landscape projects. Aestimum 2012, doi:10.13128/ Aestimum-13155.

2. Council of Europe. In Proceedings of the European Landscape Convention, CoE Treaty Series 176, Strasburg, France, 20 October 2000.

3. Castiglioni, B.; de Marchi, M. Paesaggio, Sostenibilità, Valutazione; Quaderno 24 del Dipartimento di Geografia; Castiglioni, B., de Marchi, M., Eds.; Università di Padova: Padova, Italy, 2007.

4. Turner, R.K. Sustainable Environmental Management; Westview Press: Boulder, CO, USA, 1989.

5. Aprile, M. Sul Paesaggio-Questioni, Riflessioni, Metodologie di Progetto; Aprile, M., Ed.; Franco Angeli: Milano, Italy, 2007.

6. Morin, E. La sfida della Complessità; Feltrinelli: Milano, Italy, 1993.

7. Meyer, B.C.; Grabaum, R. MULBO: Model framework for multicriteria landscape assessment and optimisation. A support system for spatial land use decisions. Landsc. Res. 2008, 33, 155-179.

8. Miccoli, S. Valorizzazione dei beni pubblici e sviluppo del territorio. Aspetti attuativi e valutativi di progetti complessi. In Le Occasioni del nuovo Prg di Roma. Valutazioni e Progetti di Valorizzazione; Passeri, A., Ed.; Aracne Editrice: Roma, Italy, 2005.

9. Kleinschmidt, V.; Wagner, D. Strategical Environmental Assessment in Europe; Kluwer: Dordrecht, The Netherlands, 1999.

10. Geuss, R. Public Goods, Private Goods; Princeton University Press: Princeton, NJ, USA, 2001.

11. Weisbrod, B.A. Collective consuption services of individual consuption goods. Q. J. Econ. 1964, $78,471-477$.

12. Krutilla, J. Conservation Reconsidered. Am. Econ. Rev. 1967, 57, 777-786. 
13. Fagerholm, N.; Käyhkö, N.; Ndumbaro, F.; Khamis, M. Community stakeholders' knowledge in landscape assessments-Mapping indicators for landscape services. Ecol. Indic. 2012, 18, 421-433.

14. Zube, E.H. Perceived land use patterns and values. Landsc. Ecol. 1987, 1, 37-45.

15. Brown, G. Mapping spatial attributes in survey research for natural research management: Methods and applications. Soc. Nat. Resour. 2005, 18, 17-39.

16. Williams, D.R.; Patterson, M.E. Environmental meaning and ecosystem management: Perspectives from environmental psychology and human geography. Soc. Nat. Resour. 1996, 9, 507-521.

17. Forte, C. Valore di scambio e valore d'uso sociale dei beni culturali immobiliari; Il Restauro: Napoli, Italia, 1977.

18. Pearce, D.W.; Markandia, A.; Barbier, E. Blueprint for a Green Economy; Earthscan: London, UK, 1989.

19. Carson, R.T.; Nicholas, E.; Cameron Mitchell, F.; Cameron Mitchell, R. The Theory and Measurement of Passive Use Value. In Valuing Environmental Preferences: Theory and Practice of the Contingent Valuation Method in the US, EC, and Developing Countries; Bateman, I.J., Willis, K.G., Eds.; Oxford University Press: Oxford, UK, 1999.

20. Brookshire, D.; Randall, A. Estimating option and existence value for wildlife resources. Land Econ. 1983, 59, 1-15.

21. Palmer, J. Research Agenda for Landscape Perception. Available online: http://193.25.34.143/ studiengaenge/mla/mla_fl/conf/pdf/conf2003/52palmer.pdf (accessed on 1 September 2014).

22. García, J.M.; Cañas, I. La valoración del paisaje. In Gestión Sostenible de Paisajes Rurales. Técnicas de Ingeniería; Ayuga, F., Ed.; Mundi-Prensa: Madrid, Spain, 2001.

23. Pearce, D.W.; Turner, R.K. Economics of Natural Resources and the Environment; Hervesr Weathsheaf: New York, NY, USA, 1990.

24. Sayadi, S.; González Roa, M.C.; Calatrava, J. Estudio de preferencias por los elementos agrarios del paisaje mediante los métodos de análisis conjunto y valoración contingente. Economía Agraria y Recursos Naturales 2004, 4, 135-151.

25. Morey, E.; Thiene, M.; de Salvo, M.; Signorello, G. Using attitudinal data to identify latent classes that vary in their preference for landscape preservation. Ecol. Econ. 2008, 68, 536-546.

26. González, M.; León, C.J. Consumption process and multiple valuation of landscape attributes. Ecol. Econ. 2003, 45, 159-169.

27. Moran, D. The economic valuation of rural landscapes. Research Study AA211 SEERAD. Edinburgh, UK, 2005. Available online: http://snh.org.uk/pdfs/strategy/landscapes/Annex.pdf (accessed on 1 October 2014).

28. Bateman, I.J.; Carson, R.T.; Day, B.H.; Hanemann, W.M.; Hanley, N.; Hett, T.; Lee, M.J.; Loomes, G.; Mourato, S.; Özdemiroglu, E.; Pearce, D.W. Economic Valuation with Stated Preferences Techniques: A Manual; Edward Elgar: Cheltenham, UK, 2002.

29. Adamowicz, W.; Boxall, P.; Williams, M.; Louviere, J. Stated preference approaches for measuring passive use values: Choice experiment and contingent valuation. Am. J. Agric. Econ. 1998, 80, 64-75.

30. Bennett, J.; Blamey, R. The Choice Modelling Approach to Environmental Valuation; Edward Elgar: Cheltenham, UK, 2001.

31. Pearce, D.W.; Özdemiroglu, E. Economic Valuation with Stated Preference Techniques; Department for Transport; Local Government and the Regions: Rotherham, UK, 2002. 
32. Campbell, D. Willingness to pay for rural landscape improvements: Combining mixed logit and random-effects models. J. Agric. Econ. 2007, 58, 467-483.

33. Sayadi, S.; González-Roa, M.C.; Calatrava-Requena, J. Public preferences for landscape features: The case of agricultural landscape in mountainous Mediterranean areas. Land Use Policy 2009, 26, 334-344.

34. Blazy, J.; Carpentier, A.; Thomas, A. The willingness to adopt agro-ecological innovations: Application of choice modelling to caribbean banana planters. Ecol. Econ. 2011, 72, 140-150.

35. Colombo, S.; Hanley, N.; Calatrava-Requena, J. Designing policy for reducing the off-farm effects of soil erosion using choice experiments. J. Agric. Econ. 2005, 56, 81-95.

36. Domínguez-Torreiro, M.; Soliño, M. Provided and perceived status quo in choice experiments: Implications for valuing the outputs of multifunctional rural areas. Ecol. Econ. 2011, 70, 2523-2531.

37. McVittie, A.; Moran, D.; Allcroft, D.; Elston, D. Beauty, beast and biodiversity: What does the public want from agriculture? In Proceedings of the 78th Annual Conference of Agricultural Economics Society, Imperial College, South Kensington, London, UK, 2-4 April 2004.

38. Hanley, N.; Colombo, S.; Tinch, D.; Black, A.; Aftab, A. Estimating the benefits of water quality improvements under the Water Framework Directive: Are benefits transferable? Eur. Rev. Agric. Econ. 2006, 33, 391-413.

39. Carlsson, F.; Frykblom, P.; Lagerkvist, C.J. Consumer willingness to pay for farm animal welfare: Mobile abattoirs versus transportation to slaughter. Eur. Rev. Agric. Econ. 2007, 34, 321-344.

40. Santos, J.M.L. The Economic Valuation of Landscape Change: Theory and Policies for Landscape Conservation; Edward Elgar: Cheltenham, UK, 1998.

41. Nijkamp, P. Quantity and Quality-Evaluation indicators for our cultural-Architectural heritage. Res. Memo. 1989, 46, 1-32.

42. Nijkamp, P.; Rietveld, P.; Voogd, H. Multicriteria Evaluation in Physical Planning; North Holland Publ.: Amsterdam, The Netherlands; New York, NY, USA, 1990.

43. Hill, M. Planning for Multiple Objectives; Monograph Series, Regional Science Research Institute: Philadelphia, PA, USA, 1973.

44. Miccoli, S. Grandi aree urbane degradate. Valutazioni per la Riqualificazione; Miccoli, S., Ed.; DEI-Tipografia del Genio Civile: Roma, Italy, 2008.

45. Gomez Sal, A.; Belmontes, J.A.; Nicolau, J.M. Assessing landscape values: A proposal for a multidimensional conceptual model. Ecol. Model. 2003, 168, 319-341.

46. Zeleny, M. Multicriteria Decision-Making; McGraw-Hill Book Company: New York, NY, USA, 1982.

47. Malczewski, J. GIS-based multicriteria decision analysis: A survey of literature. Int. J. Geogr. Inf. Sci. 2006, 20, 703-726.

48. Geneletti, D. Expert panel-based assessment of forest landscapes for land use planning. Mt. Res. Dev. 2007, 27, 220-223.

49. Caloni, N. Análisis Espacial de Evaluación Multicriterio en la Generación de Alternativas Viales Para el Trazado de la Autopista Luján-Mercedes, Buenos Aires, Argentina. B.S. Thesis de Licenciatura, Universidad Nacional de Luján, Argentina, Spain, 2003.

50. MacDonald, M.L. A multi-attribute spatial decision support system for solid waste planning. Comput. Environ. Urban Syst. 1996, 20, 1-17. 
51. Gomes, E.G.; Lins, M.P.E. Integrating geographical information systems and multi-criteria methods: A case study. Ann. Oper. Res. 2002, 116, 243-269.

52. Pereira, J.M.; Duckstein, L. A multiple criteria decision-making approach to GIS-based land suitability evaluations. Int. J. Geogr. Inf. Syst. 1993, 7, 407-424.

53. Bojórquez-Tapia, L.; dí az-Mondragón, S.; Ezcurra, E. GIS-based approach for participatory decision making and land suitability assessment. Int. J. Geogr. Inf. Sci. 2001, 15, 129-151.

54. Cipollini, K.; Maruyama, A.L.; Zimmerman, C.L. Planning for restoration: A decision analysis approach to prioritization. Restor. Ecol. 2005, 13, 460-470.

55. Kangas, J.; Kangas, A. Multiple criteria decision support in forest management-The approach, methods applied, and experiences gained. For. Ecol. Manag. 2005, 207, 133-143.

56. Orsi, F.; Geneletti, D.; Newton, A. Towards a common set of criteria and indicators to identify forest restoration priorities: An expert panel-based approach. Ecol. Indic. 2010, 11, 337-347.

57. Popper, K.R. Open Society and Its Enemy; George Routledge \& Sons, Ltd.: London, UK, 1966.

58. Lichfield, N. Economics in Urban Conservation; Cambridge University Press: Cambridge, UK, 1988.

59. Sen, A. Choice, Welfare and Measurement; BasilBlackwell: Oxford, UK, 1982.

60. Douglass, M.; Friemann, J. Cities for Citizens: Planning and the Rise of Civil Society in a Global Age; John Wiley: New York, NY, USA, 1988.

61. Miccoli, S.; Finucci, F.; Murro, R. Evaluation-Sharing in Landscape Enhancement. Dynamics of Land Values and Agricultural Policies; Crescimanno, M., Casini, L., Galati A., Eds.; Editografica: Bologna, Italy, 2013.

62. Putnam, R. Capitale Sociale e Individualismo; Il Mulino: Bologna, Italy, 2004.

63. Stenseke, M. Local participation in cultural landscape maintenance: Lessons from Sweden. Land Use Policy 2009, 26, 214-223.

64. Hilts, S.G. Achieving sustainability in rural land management thorough landowner involvement in stewardship programmes. In Agricultural Restructuring and Sustainability-A Geographical Perspective; Rickard, I.C., Ed.; CAB International: New York, NY, USA, 1997.

65. Baker, R. Landcare: An Australian response to land degradation. In Reshaping of Rural Ecologies, Economies and Communities; Pierce, J.T., Prager, S.D., Smith, R.A., Eds.; Simon Fraser University: Vancouver, BC, Canada, 2000.

66. Berkes, F.; Folke, C.; Colding, J. Linking Social and Ecological Systems. In Management Practices and Social Mechanisms for Building Resilience; Berkes, F., Folke, C., Colding, J., Eds.; Cambridge University Press: Cambridge, UK, 1998.

67. Buch, M.; Hoverman, S. Understanding public participation in forest planning: A review. For. Policy Econ. 2000, 1, 15-25.

68. O'Riordan, T.; Stoll-Kleemann, S. Biodiversity, Sustainability and Human Communities; O’Riordan, T., Stoll-Kleemann, S., Eds.; Cambridge University Press: Cambridge, UK, 2002.

69. Miccoli, S.; Finucci, F.; Murro, R. A direct deliberative evaluation procedure to choosing project for Via Giulia in Rome. Pollack Periodica. Int. J. Eng. Inform. Sci. 2014, in press.

70. Oreszczyn, S.; Lane, A. The meaning of hedgerows in the English landscape: Different stakeholder perspectives and the implications for future hedge management. J. Environ. Manag. 2000, 60, 101-118.

71. Dienel, P. Die Planungszelle: Der Bürger als Chance; Westdeutscher Verlag: Wiesbaden, Germany, 2002. 
72. Smith, G.; Wales, C. Citizen Juries and Deliberative Democracy. Polit. Stud. 2000, 48, 51-65.

73. Fishkin, J. Democracy and Deliberation: New Directions for Democratic Reform; Yale University Press: New Haven, CT, USA, 2000.

74. Danish Board of Technology. The Consensus Conference. Available online: http://www.tekno.dk (accessed on 1 September 2014).

75. Habermas, J. Theorie des kommunikativen Handelns; Suhrkamp: Frankfurt a.M., Germany, 1981.

76. Miccoli, S.; Finucci, F.; Murro, R. Toward Integrated Urban Agricolture Systems: Economic and Valuation Aspects. Aestimum 2014, in press.

(C) 2014 by the authors; licensee MDPI, Basel, Switzerland. This article is an open access article distributed under the terms and conditions of the Creative Commons Attribution license (http://creativecommons.org/licenses/by/4.0/). 